\title{
Hydration state diagnosis in fractal flow-field based polymer electrolyte membrane fuel cells using acoustic emission analysis
}

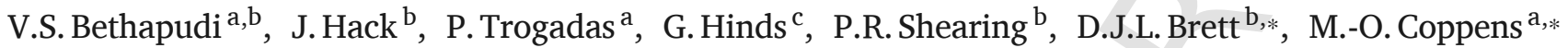 \\ a EPSRC "Frontier Engineering" Centre for Nature Inspired Engineering \& Department of Chemical Engineering, University College London, London WC1E 7JE, United Kingdom \\ $\mathrm{b}$ Electrochemical Innovation Lab, Department of Chemical Engineering, University College London, London WC1E 7JE, United Kingdom \\ ${ }^{\mathrm{c}}$ National Physical Laboratory, Hampton Road, Teddington, Middlesex TW11 OLW, United Kingdom
}

\section{A R T I C L E I N F O}

\section{Keywords}

Acoustic emission

Acoustic activity

Fractal

Flooding

Water management

Non-destructive testing

Fuel cell

\begin{abstract}
A B S T R A C T
Techniques for evaluating water management are critical to diagnose the performance of polymer electrolyte membrane fuel cells (PEMFCs). Acoustic emission as a function of polarisation (AEfP) has been recently introduced as a non-invasive, non-destructive method to analyse the water generation and removal inside a PEMFC during polarisation. AEfP was shown to provide unique insight into water management within a conventional PEMFC and correlating it to cell performance. Here, AEfP is used to characterise the performance of fractal PEMFCs by evaluating the hydration conditions inside them. This is achieved by probing the water dynamics inside two different fractal flow-field based PEMFCs, namely 1-way and 2-way fractal PEMFCs, and measuring the corresponding acoustic activity generated from them. AEfP is performed on the fractal PEMFCs under relatively humid $(70 \% \mathrm{RH})$ and fully humidified $(100 \% \mathrm{RH})$ reactant relative humidity $(\mathrm{RH})$ conditions. Flooding in the 2-way fractal PEMFC, as opposed to the 1-way fractal PEMFC, is demonstrated under different operating conditions by the relatively higher acoustic activity it generates. Corroborating evidence of flooding in the 2-way fractal flow-field under different conditions is provided by its polarisation curves, impedance tests and galvanostatic (current hold) measurements.
\end{abstract}

\section{Introduction}

Understanding water management is critical in evaluating the performance and durability of polymer electrolyte membrane fuel cells (PEMFCs) [1]. Water inside a PEMFC arises from electrochemical reaction at the cathode and humidification of the reactant streams. Sufficient hydration is essential to maintain optimal membrane conductivity. Improper hydration can result in membrane degradation, thus impacting PEMFC longevity $[2,3]$. However, too much water in the system can lead to flooding, resulting in reactant starvation and severe performance losses, particularly at higher current density [3,4].

Flooding in a PEMFC can be identified by reduced polarisation performance [4,5], increased mass and charge transport resistance [6], fluctuations or spikes in voltage and current density distribution [7], and material degradation or corrosion of cell components [8]. However, these are indirect symptoms, limited in terms of their ability to evaluate and quantify the water distribution inside a PEMFC. Direct water evaluation can be achieved using X-ray radiography, to help determine the influence of liquid water on PEMFC performance [9] and the time-dependent droplet behaviour in a flow-field channel [10]. In addition, X-ray computed tomography can be used to understand the relationship between the structure of the gas diffusion medium and water distribution [11], or the geometrical land and channel effects on spatial liquid water distribution in gas-diffusion layers of PEMFCs [12]. Another common technique is neutron radiography, which can be employed to validate cell voltage and water content in PEMFC [13], visualise liquid water in flow-fields [14], and investigate the effect of flow-field design on the performance of PEMFCs [15]. Finally, optical photography can be used to picture water build-up in the cathode region of a transparent PEMFC [16] and visualise two-phase flow in a PEMFC flow-field [17]. Still, these techniques suffer from certain limitations in terms of their application to PEMFCs, like complexity in operation, radiation exposure, accessibility, cost, and restrictions in the materials that can be used.

Acoustic emission (AE) involves the generation of spontaneous elastic waves, due to release of energy from a material or system undergoing mechanical perturbation [18]. The elastic waves then propagate through the material to be generated into detectable $\mathrm{AE}$ signals. AE-based monitoring and analysis is a non-invasive and non-destructive testing (NDT) process that has been instrumental in the study and characterisation of a wide range of applications, from small to industrial scales, such as medical diagnostics and therapeutics [19], and fa-

\footnotetext{
* Corresponding authors at: Department of Chemical Engineering, University College London, Torrington Place, WC1E 7JE, London.

E-mail addresses: d.brett@ucl.ac.uk (D.J.L. Brett); m.coppens@ucl.ac.uk (M.-MO.-O Coppens)
} 
tigue of metal plates [20]. AE-based analysis of electrochemical processes has been applied in studying corrosion, like cracking of stainless steel [21] and the structure of steel-reinforced concrete beams [22], in battery technology for the study of electrodes [23,24], lifetime evaluation of Li-ion batteries [25] and safety assessment tests [26], and in electrolysers for performance analysis and as in situ diagnostic tool [27]. However, discrepancies in AE analysis can occur from the interference of elastic waves generated from the surrounding material and ambient conditions. Hence, to avoid such external disturbances, careful isolation of the target measurement is necessary, especially with a set of threshold acoustic conditions that will subtract the AE generated from the surrounding conditions [28]. In the field of fuel cells, AE has been utilised in understanding the thermo-physical characteristics of a solid oxide fuel cell [29], the water uptake of Nafion membrane and the impact of water content on the dimensional changes occurring in a membrane $[30,31]$ and the performance diagnosis of a PEMFC under different operating conditions [28]. Legros et al. [28] performed AE-based characterisation of a PEMFC under different cell configurations and operating conditions. They identified that $\mathrm{AE}$ from a PEMFC is sensitive to the hydrodynamics of gas flow in the flow-field channels. Building on this preliminary analysis, Bethapudi et al. [32] developed a new method, called acoustic emission as a function of polarisation (AEfP) and explored fuel cell operation over a range of current density, reactant relative humidity $(\mathrm{RH})$ and cell operating temperature. AEfP represents the acoustic activity from a PEMFC, generated through mechanical events associated with liquid water droplets emerging from the gas diffusion layer (GDL) and being transported along flow-fields, where they impinge on channel walls. Acoustic events are measured in terms of cumulative absolute acoustic emission energy (CAEE) of the acoustic hits generated at discrete points of fuel cell polarisation. The method was instrumental in identifying the discrete and cumulative effects of reactant $\mathrm{RH}$ and operating conditions on the AE activity generated from a PEMFC. AEfP could relate cell performance with acoustic activity. Stable and degraded performance was correlated with low and high levels of acoustic activity, respectively.

Previously, PEMFCs using a fractal flow-field at the cathode, which was inspired by the air flow distribution mechanism inside lungs, were shown to deliver better performance, as a result of homogenous, scalable and uniform reactant distribution, compared to the PEMFCs based on conventional, single-serpentine flow-fields [33-36]. Details on the theoretical foundations and methodology behind the lung-inspired, fractal flow-fields can be found in previous works by the Coppens group $[37,38]$. The performance enhancement in fractal PEMFCs was realised over a range of operating conditions, especially when there are mass transport limitations in conventional fuel cell designs. This improvement can be attributed to the fractal branching air supply,

a)

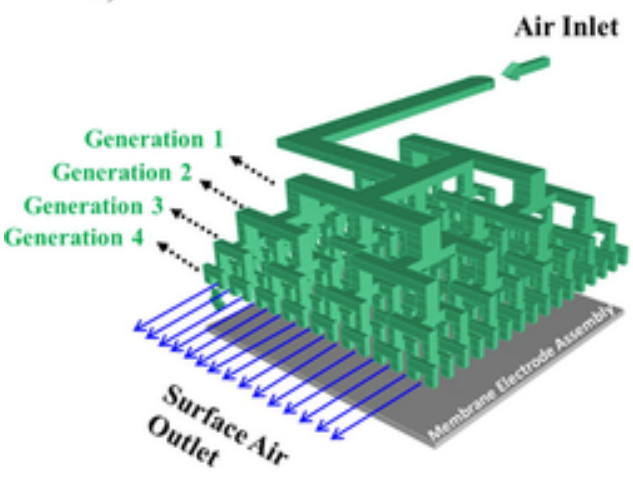

which allows for more uniform distribution of reactants and water removal from the fuel cell [39].

Here, a new fractal flow-field, which has an increased contact area compared to the previous one [39] is designed, constructed and tested. This flow-field contains an embedded, fractal branched water egress mechanism, while the previous one with less contact area includes a more direct means of water egress from the system. Impacts of contact area and water removal mechanism, together and individually, on the performance of fractal PEMFCS are evaluated through polarisation measurements and other conventional characterisation techniques. Furthermore, the AEfP method is utilised to characterise the performance of fractal PEMFCs, under different operating conditions, by diagnosing the hydration conditions inside the cells. The acoustic activity from the fractal PEMFCs during consecutive polarisation cycles, and the quantification of the corresponding hydration levels developed inside the cell using amplitude analysis, allow the relative water management characteristics of the two fractal flow-fields to be compared. Generic PEMFC performance characterisation, including electrochemical impedance measurements and galvanostatic tests, is performed to further establish the correlations between cell design, performance and AE activity.

\section{Experimental}

\subsection{Design of fractal PEMFC flow-fields}

PEMFCs used in this study have a single-serpentine based flow-field at the anode, and a hierarchically structured fractal flow-field at the cathode. Two different configurations of cathode fractal flow-field, namely "1-way" (less contact area with direct means of water egress through surface air outlets) and "2-way" (increased contact area with convoluted, fractal means of water egress) were developed, as shown in Fig. 1.

Previously, layer-wise, planar printed circuit board (PCB) based assembly was identified to be an easy and cost-effective manufacturing approach to produce lightweight, durable fractal flow-fields [39]. In this study, both 1-way and 2-way fractal flow-fields were fabricated from PCB plates using a similar approach. In this layer-wise approach, several layers of planar PCB plates, each plate comprising of a specific fractal generation, are assembled to produce a fractal flow-field for the cathode [39]. Also the single-serpentine flow-field for the anode was constructed using planar PCB plates [39].

Fig. 1(a) presents the design schematic of a 1-way fractal flow-field, where the cathode air enters the membrane electrode assembly (MEA) through a fractal flow path (green) that has, in this case, four generations. A four-generation fractal flow path was used because of its superior performance compared to a conventional serpentine flow-field, as demonstrated previously [33,39]. The flow path for the cathode

b)

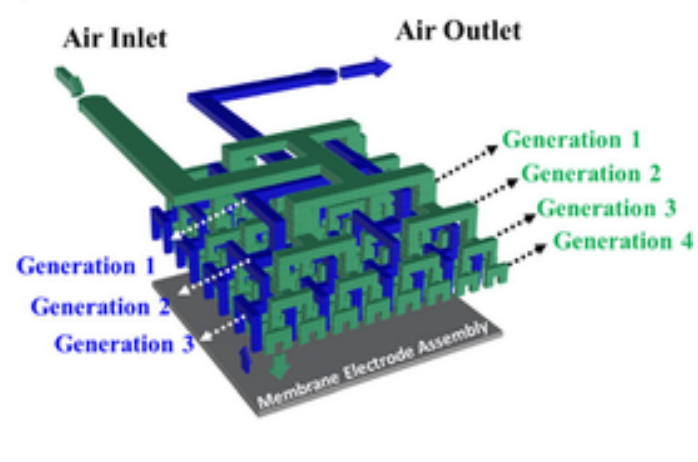

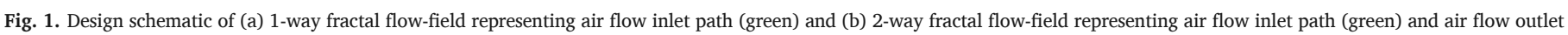
path (blue) at the cathode. (For interpretation of the references to colour in this figure legend, the reader is referred to the web version of this article.) 
air to the MEA branches from a single inlet to $4^{4}=256$ outlets at the end of the 4th generation, as shown in Fig. 1(a). Each outlet has dimensions of $400 \mu \mathrm{m} \times 800 \mu \mathrm{m}$, with $1.18 \mathrm{~mm}$ spacing between adjacent outlets. Furthermore, the air outlet from the MEA is an open-ended flow occurring via surface air outlet flow paths (blue arrows) of $0.5 \mathrm{~mm}$ width and $1 \mathrm{~mm}$ depth located within the spacing between the 4th generation outlets [39].

Fig. 1(b) presents the design schematic of the 2-way fractal flow-field, where the air distribution to the MEA (green) occurs via a four-generation fractal flow path, similar to that in the 1-way fractal flow-field (Fig. 1(a)). However, the air removal from the MEA (blue) occurs via a three-generation fractal flow path, as shown in Fig. 1(b). Here a fractal flow path to collect air from the MEA was used to increase the overall conductive flow-field area in contact with the MEA, compared to the 1-way fractal system (Supplementary Material Fig. S1). This was achieved by utilising the void spaces created by the air inlet flow path to the MEA (green), as shown in Fig. 1(a). For every-four outlets at the end of the 4th generation of air inlet points (green), it was possible to accommodate one entry point for the air outlet flow path (blue), viz. a total of $4^{3}=64$ inlets for the air outlet flow path (blue) from the MEA (Supplementary Material Fig. S1). From 64 inlets to a single outlet, the air outlet flow path merges through three fractal generations, as shown in Fig. 1(b). Furthermore, developing the air outlet flow path (blue) for the 2-way fractal within the hierarchical structure of the air inlet flow path (green) made it possible to maintain the same number of PCB plates to include both fractal flow-field concepts within a single design.

The anode flow-field, used with both tested fractal flow-fields for the cathode, had a $1 \mathrm{~mm}^{2}$ area square channel single-serpentine flow path with a depth of $1 \mathrm{~mm}$.

\subsection{PCB flow-field development}

The fabrication of flow-field features on the PCB plates was carried out using a Computer Numerical Control (CNC) machine (Roland-40, ROLAND, USA). For the cathode fractal flow-fields, seven individual PCB plates were machined that, together, produced the branching flow paths when assembled. Four plates were utilised to realise the four individual fractal generation features of the air inlet to the MEA flow path (green in Fig. 1(a) and (b)) and three plates were utilised to create the interconnecting pathways between those four fractal generations. Furthermore, the fractal generations for the removal of air from the MEA in the 2-way fractal (blue in Fig. 1(b)) were created in those plates that also include the three interconnecting pathways to introduce air to the cathode.

For the anode flow-field, only two PCB plates were used, one plate having the single-serpentine flow path features and the other plate as a backing support.

The PCB plates adjoining the MEA, for both the cathode and the anode region, have a $35 \mu \mathrm{m}$ thick Cu-coated layer (all other seven PCB plates have no $\mathrm{Cu}$ coating) that was electroplated first with $\mathrm{Ni}$ and, subsequently, with Au. $0.13 \mathrm{M} \mathrm{Ni}\left(\mathrm{SO}_{3} \mathrm{NH}_{2}\right)_{2}$ as the Ni-plating solution and $0.02 \mathrm{M} \mathrm{KAu}(\mathrm{CN})_{2}$ as the Au-plating solution were used for the electroplating processes. Ni electroplating was performed at a current density of $4.3 \mathrm{~mA} \mathrm{~cm}^{-2}$ and a voltage range of $3.0 \mathrm{~V}-3.5 \mathrm{~V}$ for $3 \mathrm{~min}$, while the Au electroplating was performed at a current density of $2.4 \mathrm{~mA} \mathrm{~cm}^{-2}$ and a voltage range of $3.5 \mathrm{~V}-3.7 \mathrm{~V}$ for $60 \mathrm{~min}$ [39]. After electroplating, these Au coated PCB plates acted as the current collectors for the respective electrodes of the fractal PEMFCs.

The PCB plates, with pre-impregnated composite thermosetting polymer sheets between them providing the necessary adhesion, were assembled into their respective flow-fields using a hot press. The PCB plates were compressed under a pressure of 400 psig at $150{ }^{\circ} \mathrm{C}$ for $60 \mathrm{~min}$. After hot pressing, the overall dimensions of each fractal cathode flow-field plate were $80 \mathrm{~mm} \times 80 \mathrm{~mm} \times 9.6 \mathrm{~mm}$ and the dimen- sions of the anode single-serpentine flow-field plate were $80 \mathrm{~mm} \times 80 \mathrm{~mm} \times 3.5 \mathrm{~mm}$ [39]. The final, assembled 1-way and 2-way fractal cathode flow-fields are shown in the Supplementary Material Fig. S1.

\subsection{Membrane electrode assembly (MEA)}

The MEA components used in this study were Nafion ${ }^{\circledR} 212$ membrane, HyPlat Pt catalyst (HyPlat, South Africa) coated gas diffusion electrodes, with a catalyst loading of $0.4 \mathrm{mg}_{\mathrm{Pt}} \mathrm{cm}^{-2}$ and Freudenberg H23C9 GDLs (carbon fibre paper with PTFE-treated microporous layer) of $210 \mu \mathrm{m}$ thickness. The MEA components were hot pressed under an applied pressure of $400 \mathrm{psig}$ at $150{ }^{\circ} \mathrm{C}$ for $3 \mathrm{~min}$.

\subsection{X-ray computed tomography scans}

$\mathrm{X}$-ray computed tomography (X-ray CT) scans were performed on the fractal flow-fields using a Nikon XT H 225 instrument (Nikon Metrology, UK). The corresponding details on the experimental setup, scan operating conditions, acquisition conditions, and software used for image reconstruction are provided in a previous article [39].

\subsection{Testing of fractal PEMFCs}

A Scribner 850e fuel cell test station (Scribner Associates NC, USA) was used for the experimental studies. The test station had the capacity to provide $99.995 \%$ pure hydrogen under ambient conditions. In addition, it could supply reactants at desired conditions using temperature, humidity and mass flow controllers. In this study, the hydrogen flow rate was maintained at $100 \mathrm{~mL} \mathrm{~min}^{-1}$ and the air flow rate was maintained constant at $500 \mathrm{~mL} \mathrm{~min}^{-1}$. A constant air flow rate was maintained to avoid the generation of unwanted acoustic emissions occurring from the variations in velocity in stoichiometric based air flow. Polarisation measurements on the fractal flow-fields were carried out between open circuit voltage (OCV) and $0.3 \mathrm{~V}$ at intervals of $0.05 \mathrm{~V}$ and $30 \mathrm{~s}$ hold at each voltage interval point [40]. Before each polarisation, cell conditioning (stabilisation) was performed, where the PEMFC was supplied with reactants under OCV conditions for 2 min to allow the gas flow and humidity in the channels to stabilise. The fractal PEMFCs were initially heated to a start-up temperature of $45^{\circ} \mathrm{C}$ using cylindrical heaters, as discussed in [39]. The fuel cell components, assembly technique, reactant supply, cell heating and temperature measurement methodology were adapted from Bethapudi et al. [39].

\subsection{Electrochemical impedance spectroscopy}

Electrochemical impedance spectroscopy (EIS) measurements were performed using a Gamry Reference 3000 and Gamry Reference $30 \mathrm{k}$ Booster (Gamry Instruments, USA). The frequency range for analysis was $100 \mathrm{kHz}$ to $0.1 \mathrm{~Hz}$, with 10 points per decade, and an AC modulation amplitude of $5 \%$ of the DC input signal.

\subsection{Acoustic emission testing}

Acoustic activity from the fuel cell was measured using a piezoelectric acoustic sensor (transducer S9208; Mistras NDT, UK) attached to the cathode flow-field plate, as shown in Fig. 2. The sensor was connected to an in-line, low-power preamplifier, which filtered and pre-amplified the acoustic signal by $26 \mathrm{~dB}$, followed by a single-channel $\mathrm{AE}$ digital signal processor. The signal processor was connected through a USB to a PC running AEwin ${ }^{\mathrm{TM}}$ (Physical Acoustics Corporation, USA) software, which performed data collection, processing and analysis. Furthermore, the software used for processing the acoustic signals mea- 


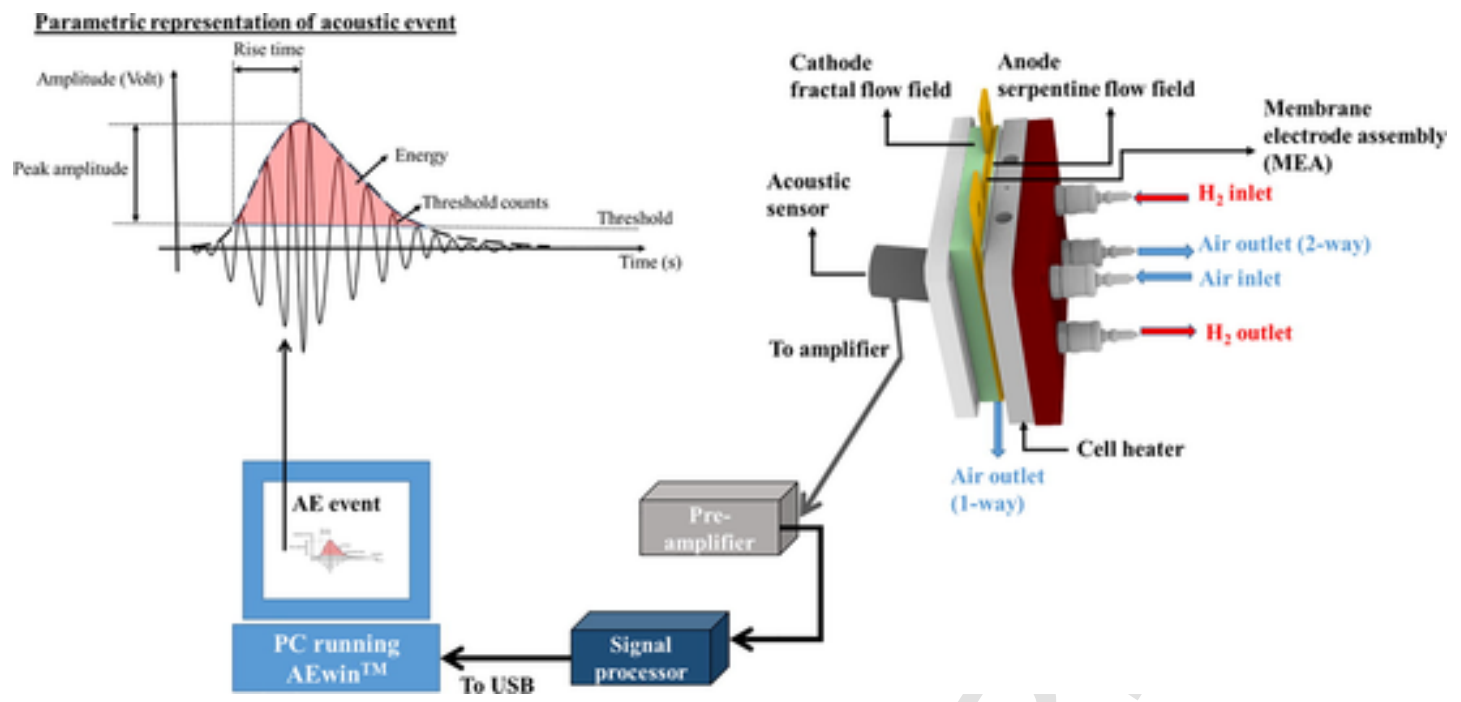

Fig. 2. Schematic representation of AE testing with the parametric representation of an acoustic event (adapted from [32]).

sured an average of the acoustic hits generated over time and filtered out the hits below a certain threshold limit.

The sensor had a resonant frequency of $500 \mathrm{kHz}$ and an operating frequency range of $200 \mathrm{kHz}-1000 \mathrm{kHz}$. The acoustic sensor was fastened against the cathode fractal flow-field, using silicone grease for coupling.

The single-channel AE acquisition system had lower and upper analogue filters of $20 \mathrm{kHz}$ and $1 \mathrm{MHz}$, respectively, and a fixed threshold value of $29 \mathrm{~dB}$. This threshold was set, taking into account the background 'noise' signal during testing, and any signal beyond this threshold value was recorded as an 'AE hit' in terms of a voltage profile, as shown in Fig. 2. The AE hit dataset primarily consisted of amplitude $(\mathrm{dB})$, counts, duration $(\mu \mathrm{s})$, rise time $(\mu \mathrm{s})$, and absolute energy $(\mathrm{a})$ $[28,32]$. In this study, the acoustic activity was presented as CAEE [32] and peak amplitude (PA) measured from individual acoustic hits, measured over a specified time interval.

\section{Results and discussion}

\subsection{X-ray CT scan}

In order to inspect the alignment of the hierarchical fractal flow-field designs and the integrity of each flow channel, X-ray CT was performed. Virtual slices from each dataset in the $x y$-plane for scans of the 1-way and 2-way fractal flow-fields are shown in Fig. 3(a) and (b), respectively.

The X-ray attenuation in the flow channels (inlet and outlet) was lower, because they are empty, hence, these were observed as dark regions, while zones containing PCB material provided higher attenuation and were observed as bright regions.

Each H-shaped, dark region in Fig. 3(a) is a segment of the flow inlet path on a PCB plate, corresponding to a specific generation in the 1-way fractal flow-field (schematically shown in Fig. 1(a)) and the holes correspond to the interconnecting pathways on a PCB plate, between generations. Fig. 3(a) also illustrates the order in which the individual PCB plates appear in the final assembly. It can be observed from the scans that all flow inlet path segments and holes, across four generations of the 1-way fractal flow-field, are clear of any distortion and misalignment.

The scan for the 2-way fractal flow-field, shown in Fig. 3(b), represents $\mathrm{H}$-shaped fractal inlet (green box) and fractal outlet (blue box) flow path segments (schematically shown in Fig. 1(b)). The inlet flow paths for the 2-way fractal were similar to those in the 1-way fractal flow-field (Fig. 3(a)). Furthermore, the fractal outlet flow paths were developed within the plates used for developing interconnecting flow paths for the 1-way fractal. This method of fabrication allowed the utilisation of the same flow-field plate thickness for both 1-way fractal and 2-way fractal flow-fields (differences in flow-field thickness can alter the AE measured). Hence, the flow-fields presented similar attenuation to the acoustic emission signals generated.

Also, Fig. 3(b) illustrates the order in which the inlet and the outlet flow paths of the 2-way fractal flow-field appear in the final assembly. The four generations of the fractal inlet (green) and three generations of the fractal outlet (blue box) can be clearly identified and are well aligned and unobstructed.

\subsection{AEfP measurements}

Polarisation and AEfP curves for the fractal flow-field PEMFCs tested are presented in Fig. 4. At 70\% RH conditions (Fig. 4a), the polarisation performance of the 2-way fractal PEMFC was slightly better than that of the 1-way fractal PEMFC in the region between OCV and $\sim 700 \mathrm{~mA} \mathrm{~cm}^{-2}$. This can be attributed to the greater conductive contact area available between the MEA and the flow-field for the 2-way fractal flow-field (Supplementary Material Fig. S1). At current densities $>700 \mathrm{~mA} \mathrm{~cm}^{-2}$, the performance of the 2-way fractal PEMFC decreased considerably with respect to the 1-way fractal PEMFC, reaching a limiting current density of $\sim 1200 \mathrm{~mA} \mathrm{~cm}^{-2}$. In contrast, the performance of the 1-way fractal PEMFC remained stable throughout its operation and attained a higher limiting current density of $\sim 1500 \mathrm{~mA} \mathrm{~cm}^{-2}$. The performance reduction for the 2-way fractal PEMFC at higher current densities can be attributed to flooding within the cell due to inefficient water removal, impeding effective reactant (oxygen) transport to the electrode [41-43].

Observing the acoustic activity for the $70 \% \mathrm{RH}$ case, as shown in Fig. 4(c), between OCV and $\sim 0.65 \mathrm{~V}\left(\sim 700 \mathrm{~mA} \mathrm{~cm}^{-2}\right)$ the increase in CAEE for both fractal PEMFCs is similar, implying similar amounts of liquid water in the flow-fields [32]. Similar liquid water levels are maintained in the flow-field for each system; the superior performance of the 2-way fractal PEMFC at lower current density is attributed to the greater land-electrode surface area, which reduces the Ohmic resistance of the system (Fig. 4(a)). However, above $800 \mathrm{~mA} \mathrm{~cm}^{-2}(\sim 0.6 \mathrm{~V})$, the increase in CAEE for the 2-way fractal PEMFC is much larger than that for the 1-way fractal PEMFC, implying greater liquid water activity with the 2-way design. This results in electrode flooding and degradation of cell performance, as seen in Fig. 4(a). The lower CAEE observed for the 1-way fractal PEMFC, as seen in Fig. 4(c), implies 
a)
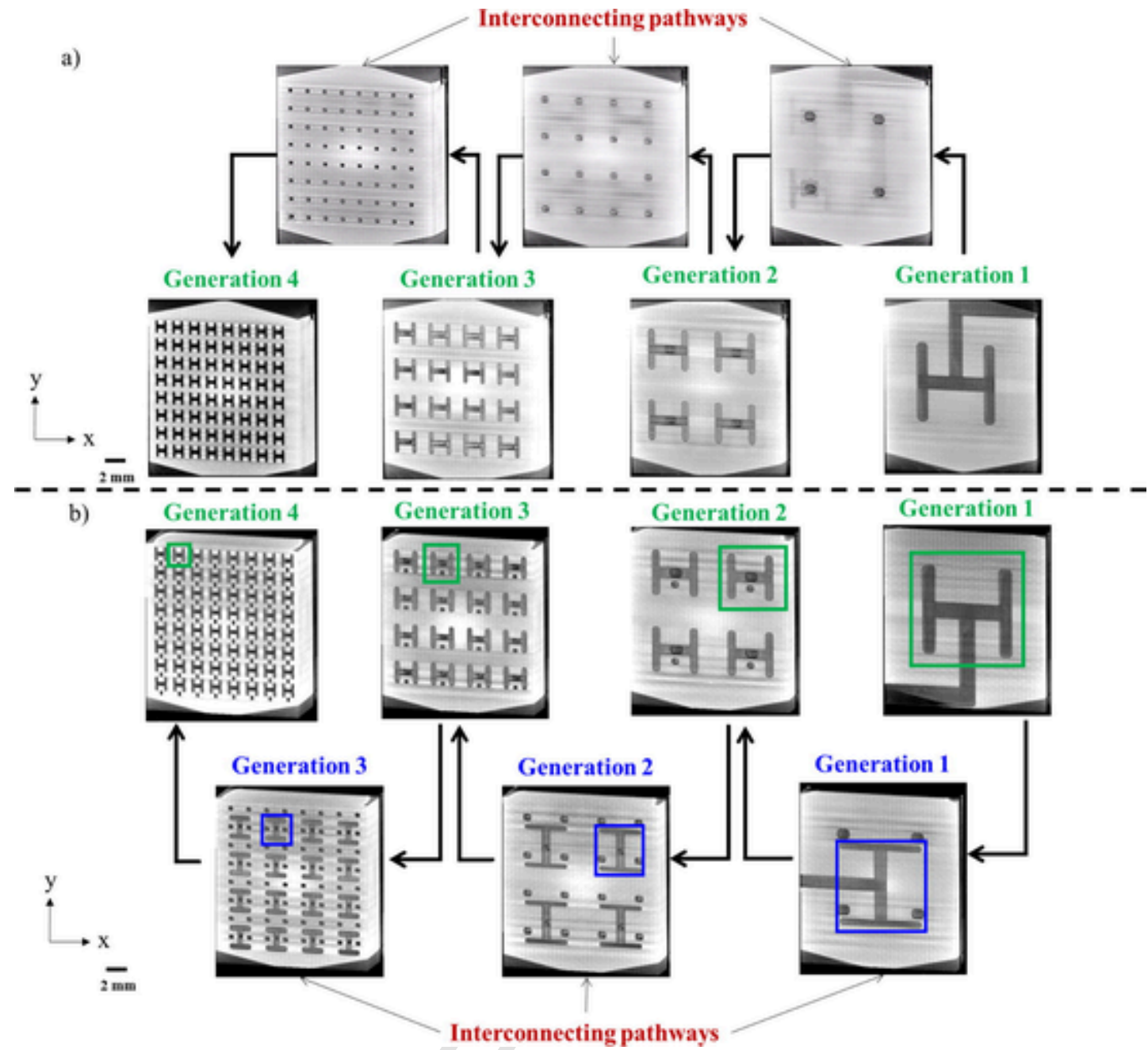

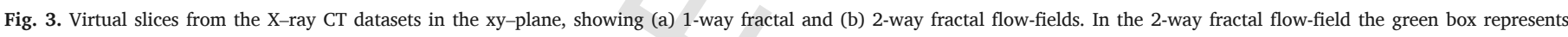

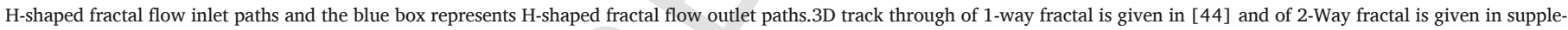
mentary video. (For interpretation of the references to colour in this figure legend, the reader is referred to the web version of this article.)

less extensive flooding and results in more sustained polarisation performance to higher current density.

Note that the point in the AEfP profile at which the CAEE increases sharply is $\sim 0.6 \mathrm{~V}$ for the 1-way design and $\sim 0.5 \mathrm{~V}$ for the 2-way design, which corresponds to the 'roll-off' in polarisation for each. This confirms that the mass transport limitation effect is predominantly a liquid water based phenomenon for this system.

By controlling the air supply's $\mathrm{RH}$, it is possible to control the amount of water within the system, for any given current density. For the $100 \% \mathrm{RH}$ case, the corresponding polarisation performance and AEfP for the fractal PEMFCs are shown in Fig. 4(b) and (d). As for the $70 \% \mathrm{RH}$ case, the 2-way design performs slightly better at low current density, due to greater contact surface area with the electrode. With increasing current density, a more significant decrease in cell performance is observed for the 2-way fractal PEMFC, compared to the 1-way fractal PEMFC, than for the $70 \% \mathrm{RH}$ case. In addition, the limiting current density attained with the 2-way fractal design is $\sim 1000 \mathrm{~mA} \mathrm{~cm}^{-2}, \sim 200 \mathrm{~mA} \mathrm{~cm}^{-2}$ less than that achieved for the $70 \%$ $\mathrm{RH}$ case. The marked decrease in the overall performance of the 2-way fractal PEMFC using highly humidified reactants $(100 \% \mathrm{RH})$ can be attributed to exacerbated flooding in the cell. This is consistent with a higher rate of water condensation from the highly humid reactants, in addition to the water generated from the electrochemical reaction with increasing current density $[44,45]$.
Corroborating evidence for exacerbated flooding inside the 2-way fractal flow-field was provided by the AEfP measurements: Fig. 4(d) indicates that at $100 \% \mathrm{RH}$ the abrupt increase in CAEE for the 2-way fractal PEMFC occurs at a much lower current density $\left(\sim 400 \mathrm{~mA} \mathrm{~cm}^{-2}\right)$ compared to the $70 \% \mathrm{RH}$ case $\left(\sim 800 \mathrm{~mA} \mathrm{~cm}^{-2}\right)$. Furthermore, the magnitude of the CAEE observed with the 2-way fractal PEMFC during polarisation increased significantly with $\mathrm{RH}$, from $\sim 750$ aJ at $70 \% \mathrm{RH}$ to $\sim 2250$ aJ at $100 \% \mathrm{RH}$ at the limiting current density. These observations are consistent with the increase in performance drop and the decrease in limiting current density indicated by the electrochemical measurements.

In contrast, the performance of the 1-way fractal PEMFC increased with reactant RH [46]. The increase in CAEE (from $\sim 600$ aJ at $70 \%$ $\mathrm{RH}$ to $\sim 1000$ aJ at $100 \% \mathrm{RH}$ ) with humidity may reflect an optimal rise in the membrane hydration and its associated conductivity occurring due to improved generation and distribution of water at the electrodes, which increased the limiting current density attained from $\sim 1400 \mathrm{~mA} \mathrm{~cm}^{-2}$ (70\% RH) to $\sim 1600 \mathrm{~mA} \mathrm{~cm}^{-2}$ (100\% RH) [47].

Overall, the polarisation and AEfP measurements confirm that the 2-way fractal PEMFC was significantly limited by flooding, whilst the 1-way fractal PEMFC was closer to optimal with respect to hydration. The surface flow channels (blue arrows in Fig. 1(a)) of the cathode air outlet in the 1-way fractal flow-field allow effective water removal via a straight path, compared with the more tortuous cathode air out- 
a)

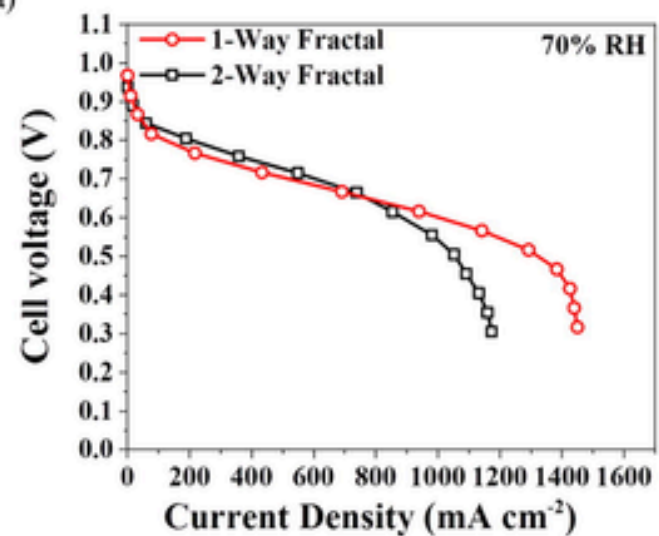

c)

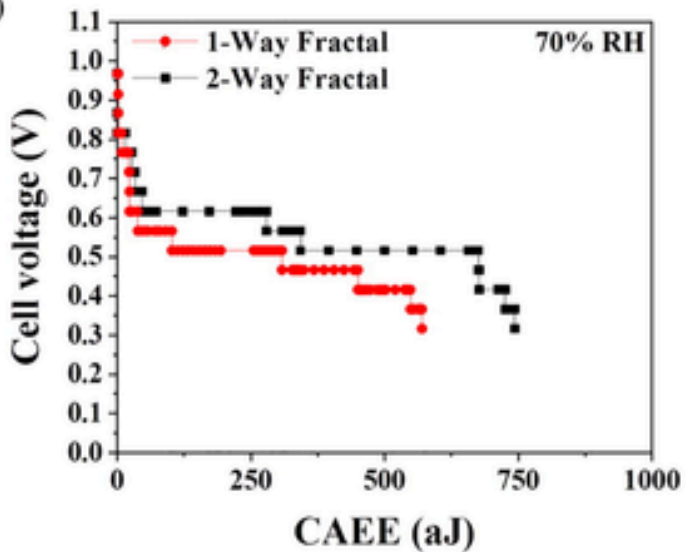

b)

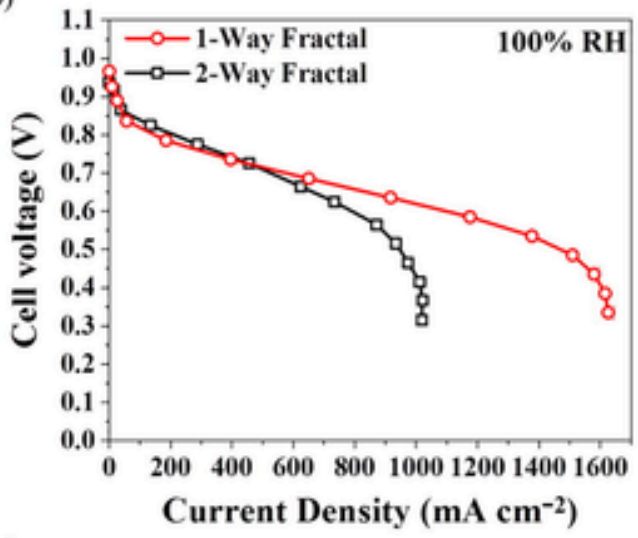

d)

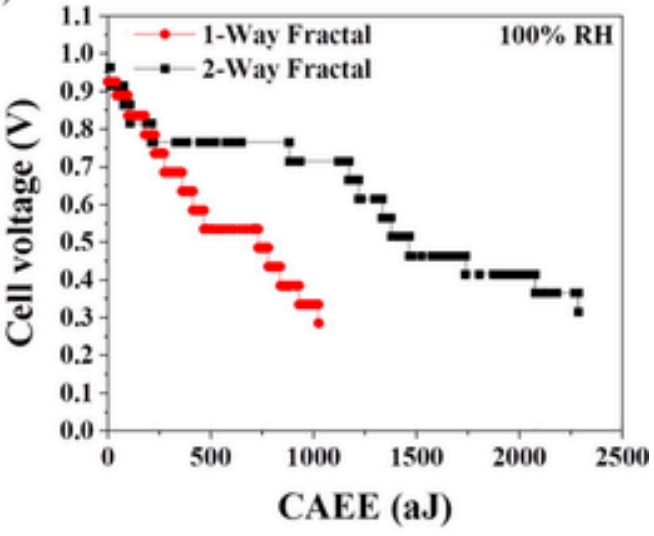

Fig. 4. Polarisation curves at (a) 70\% reactant RH and (b) 100\% reactant RH; AEfP curves at (c) 70\% reactant RH and (d) $100 \%$ reactant RH.

let flow channels (blue arrows in Fig. 1(b)) in the 2-way fractal flow-field, which are not effectively flushed and result in more liquid water stagnation and electrode flooding.

\subsection{Electrochemical impedance spectroscopy}

High frequency resistance (HFR) values, presented in Fig. 5, were measured from the high-frequency, real-axis intercept of the Nyquist plot of the EIS measurements. The HFR represents the overall Ohmic resistance developed in a PEMFC $[48,49]$. An increase in HFR is observed when the membrane becomes dehydrated, which results in reduced membrane conductivity, and vice versa [50]. However, for

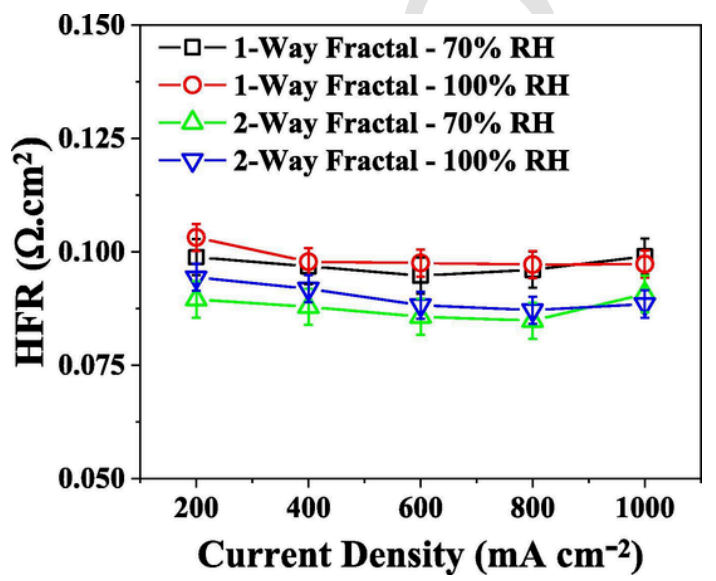

Fig. 5. High frequency resistance (HFR) for the fractal PEMFCs tested at different reactant $\mathrm{RH}$ and current density conditions, all at $\mathrm{T}=45^{\circ} \mathrm{C}$. the fractal PEMFCs, the HFR was identified to be uniform, within 5-10\% variation, between $200 \mathrm{~mA} \mathrm{~cm}^{-2}$ and $1000 \mathrm{~mA} \mathrm{~cm}^{-2}$, as shown in Fig. 5. The relatively small difference in HFR for the fractal PEMFCs, over this current density range, indicates that the membrane was sufficiently hydrated throughout its operation, especially in the high current density region, where higher cell temperatures tend to dehydrate the membrane.

Furthermore, at a given experimental condition (reactant $\mathrm{RH}$ ), the Ohmic resistance for the 2-way fractal PEMFC is observed to be lower than that of the 1-way fractal PEMFC. This may be attributed to the increased contact area between the flow-field and MEA in the 2-way fractal (Supplementary Material Fig. S1), especially when all the other factors affecting the bulk resistance, like cell temperature, assembly torque, current density, reactant RH, etc., were constant [49]. Furthermore, the impact of reduced Ohmic resistance in the 2-way fractal PEMFC can be observed from its better performance at low current density (Fig. 4(a) and (b)). Thus, the deterioration in cell performance observed for the 2-way fractal PEMFC can be ascribed to the reduced oxygen concentrations at the membrane caused by the excessive hydration or flooding in the electrode region [51].

The Nyquist curves for EIS measurements of 1-way and 2-way fractal PEMFCs at $70 \%$ and $100 \%$ reactant RH are presented in Fig. 6(a) and (b), respectively. The corresponding charge transfer $\left(R_{c t}\right)$ and mass transfer $\left(R_{m t}\right)$ resistances are given in Table 2 (the equivalent circuit used for modelling is given in Supplementary Material Fig. S2).

At $70 \% \mathrm{RH}$, the corresponding $R_{c t}$ for the 1-way and 2-way fractal PEMFCs are very similar at $\sim 0.03 \Omega \mathrm{cm}^{2}$, within a range of $10 \%$, at $800 \mathrm{~mA} \mathrm{~cm}^{-2}$ and $1000 \mathrm{~mA} \mathrm{~cm}{ }^{-2}$ current density conditions, as observed from Table 2. However, the mass transport resistances developed in the 2-way fractal PEMFC are much larger than those devel- 

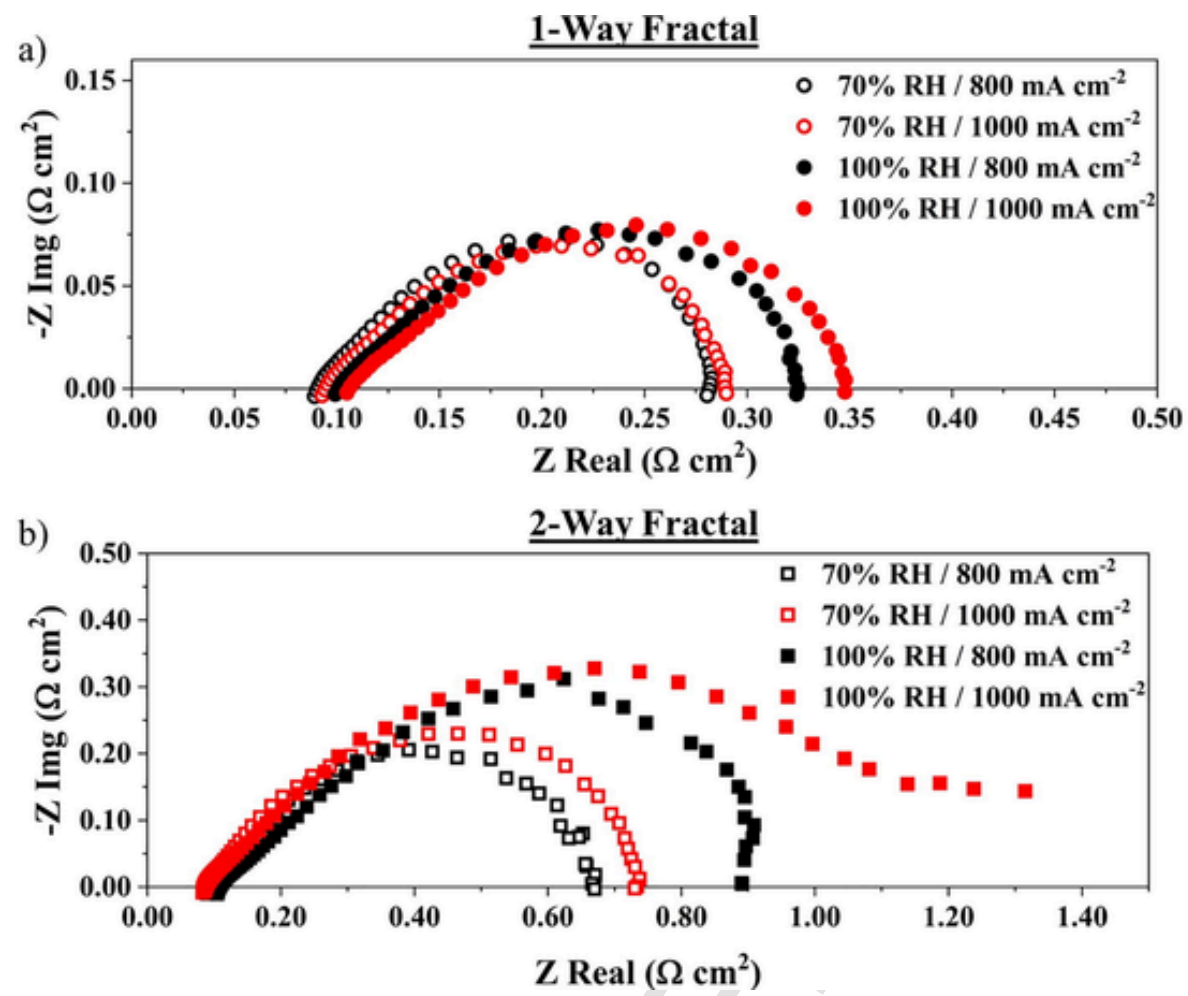

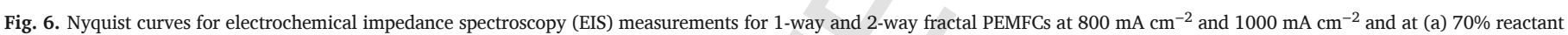
RH and (b) $100 \%$ reactant RH, respectively.

Table 1

Operating conditions for PEMFC testing.

\begin{tabular}{ll}
\hline Parameter & Value \\
\hline PEMFC testing station & Scribner 850e \\
PEMFC initial set temperature & $45^{\circ} \mathrm{C}$ \\
Cathode RH & $70 \% \& 100 \%$ \\
Anode RH & $70 \% \& 100 \%$ \\
Hydrogen flowrate & $100 \mathrm{~mL} \mathrm{~min}^{-1}$ constant \\
Air flowrate & $500 \mathrm{~mL} \mathrm{~min}^{-1}$ constant \\
Active area & $6.25 \mathrm{~cm}^{2}$ \\
Membrane & Nafion ${ }^{\circledR 2} 2$ \\
Electrode & Freudenberg H23C9 \\
EIS frequency range & $0.1 \mathrm{~Hz}-100 \mathrm{kHz}$ \\
\hline
\end{tabular}

oped in the 1-way fractal PEMFC, which can be attributed to mass transfer related issues in the 2-way fractal flow-field $[45,49,52]$.

Furthermore, at higher reactant humidity $(100 \% \mathrm{RH}), R_{c t}$ for the 1-way fractal PEMFC, at $800 \mathrm{~mA} \mathrm{~cm}^{-2}$ and $1000 \mathrm{~mA} \mathrm{~cm}^{-2}$, was similar to that at $70 \% \mathrm{RH}$, while a slight increase in the $R_{m t}$ was observed. However, in the 2-way fractal PEMFC, $R_{c t}$ increased by $29 \%$ and $36 \%$ at $800 \mathrm{~mA} \mathrm{~cm}^{-2}$ and $1000 \mathrm{~mA} \mathrm{~cm}^{-2}$, respectively. Such an increase in $R_{c t}$ with reactant RH can be attributed to the presence of some unresolved mass transport component contained in the charge transfer resistance $[49,52]$. In addition, the corresponding $R_{m t}$ for the 2-way fractal PEMFC at $800 \mathrm{~mA} \mathrm{~cm}^{-2}$ and $1000 \mathrm{~mA} \mathrm{~cm}{ }^{-2}$ was $0.89 \Omega \mathrm{cm}^{2}$ and $1.07 \Omega \mathrm{cm}^{2}$, respectively. Such large $R_{m t}$ values were developed at $100 \% \mathrm{RH}$ due to the excessive water flooding of the cell, which was already evident at $70 \% \mathrm{RH}$ at higher current densities [50,53]. This reflects the inability of the 2-way fractal flow field design to regulate excess water away from the flow-field region. However, throughout its operation, the 1-way fractal PEMFC maintained uniform water distribution in the cell, which is reflected in lower resistance values (Table 2).
Table 2

Charge transfer $\left(\mathrm{R}_{\mathrm{ct}}\right)$ and mass transfer $\left(\mathrm{R}_{\mathrm{mt}}\right)$ resistances for 1-way and 2-way fractal PEMFCs at $70 \%$ and $100 \%$ reactant $\mathrm{RH}$ and at $800 \mathrm{~mA} \mathrm{~cm}^{-2}$ and $1000 \mathrm{~mA} \mathrm{~cm}^{-2}$.

\begin{tabular}{llll}
\hline & $\begin{array}{l}\text { Current } \\
\text { density } \\
(\mathrm{mA} \\
\left.\mathrm{cm}^{-2}\right)\end{array}$ & $\begin{array}{l}\mathrm{R}_{\mathrm{ct}} \\
(\Omega \\
\left.\mathrm{cm}^{2}\right)\end{array}$ & $\begin{array}{l}\mathrm{R}_{\mathrm{mt}} \\
(\Omega \\
\left.\mathrm{cm}^{2}\right)\end{array}$ \\
\hline $\begin{array}{l}\text { Experimental condition } \\
\text { 70\% RH }\end{array}$ & 800 & 0.03 & 0.15 \\
100\% RH & 1000 & 0.03 & 0.16 \\
1-way & 800 & 0.033 & 0.18 \\
70\% RH & & & \\
2-way & 1000 & 0.035 & 0.19 \\
100\% RH & 800 & 0.031 & 0.55 \\
2-way & 1000 & 0.033 & 0.62 \\
& 800 & 0.040 & 0.89 \\
\hline
\end{tabular}

Overall, the observations from the EIS measurements provide further support for the deductions made from the CAEE measurements on the state of water distribution in the fractal flow-fields (Fig. 4).

\subsection{Cell temperature}

Cell temperatures measured simultaneously during polarisation for the fractal PEMFCs are presented in Fig. 7. It can be observed that, at $70 \% \mathrm{RH}$ (Fig. 7 (a)) and 100\% RH (Fig. 7(b)), the cell temperature profile for the 2-way fractal PEMFC is much less pronounced than that for the 1-way fractal PEMFC. Lower cell temperatures in the 2-way fractal PEMFC are a result of the cell flooding occurring during operation (confirmed by CAEE in Fig. 4(c-d)), where higher amounts of water retained by the flow-field reduce the cell temperature and lead to 
a)

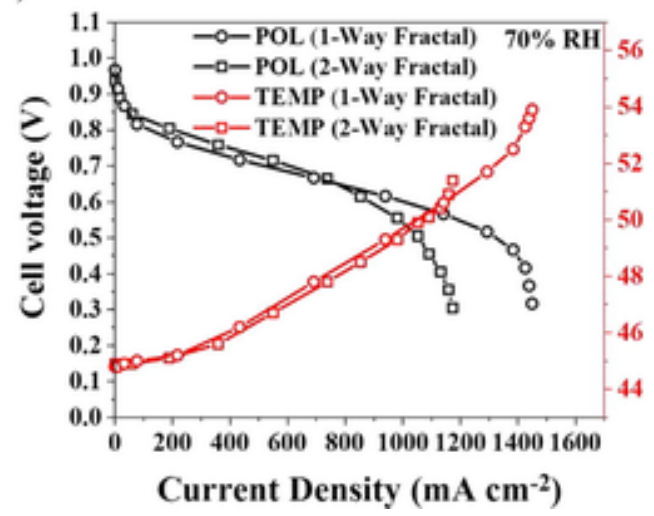

b)

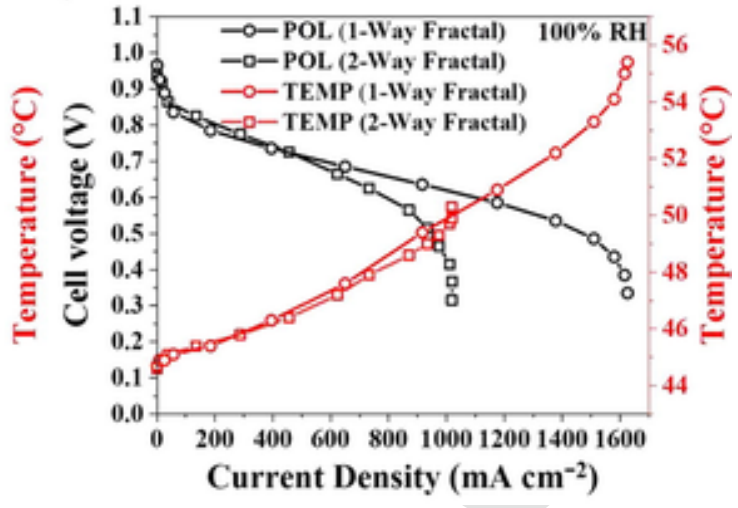

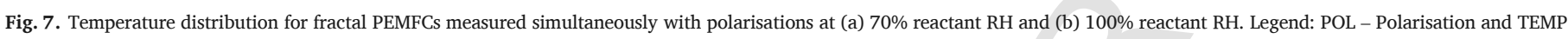
- Temperature.

a corresponding decrease in current density, and vice versa [54]. For instance, the maximum temperature attained by the 2-way fractal PEMFC reduced from $\sim 51.5{ }^{\circ} \mathrm{C}$ at $70 \% \mathrm{RH}$ to $\sim 50.3{ }^{\circ} \mathrm{C}$ at $100 \% \mathrm{RH}$; this drop in maximum cell temperature parallels a reduction in limiting current density attained from $\sim 1200 \mathrm{~mA} \mathrm{~cm}{ }^{-2}\left(70 \% \mathrm{RH}\right.$ case) to $\sim 1000 \mathrm{~mA} \mathrm{~cm}^{-2}$ (100\% RH case).

However, for the 1-way fractal PEMFC, the maximum cell temperatures attained at $70 \% \mathrm{RH}$ and $100 \% \mathrm{RH}$ were $\sim 54{ }^{\circ} \mathrm{C}$ and $\sim 55.5^{\circ} \mathrm{C}$, respectively. These temperatures were higher than those developed in the 2-way fractal PEMFC by $\sim 2.5{ }^{\circ} \mathrm{C}$ at $70 \% \mathrm{RH}$ and $\sim 5.2{ }^{\circ} \mathrm{C}$ at $100 \%$ $\mathrm{RH}$; an influence of the higher cell operating temperatures developed in the 1-way fractal PEMFC was reflected in the limiting current densities attained, which were $1400 \mathrm{~mA} \mathrm{~cm}{ }^{-2}$ at $70 \% \mathrm{RH}$ and $\sim 1600 \mathrm{~mA} \mathrm{~cm}^{-2}$ at $100 \% \mathrm{RH}$, respectively. Overall, higher operating temperatures, supported by an increase in hydration levels (Fig. 4(b) and (d)), enhanced the membrane conductivity of the 1-way fractal PEMFC and resulted in superior performance and vice versa, compared to the flooded lower-temperature operation of the 2-way fractal PEMFC $[43,55]$.

\subsection{Current density cycling}

The influence of reactant $\mathrm{RH}$ and current density (electrochemical reaction) on the increase of CAEE over time for the fractal PEMFCs was evaluated under current density cycling (successive polarisation) and is presented in Fig. 8. Each cycle in Fig. 8 is a representation of the current density generated over time, which was $420 \mathrm{~s}$ per cycle, as measured during a single polarisation. The current density was measured for the polarisation conditions outlined in Section 2.5. In addition, a $30 \mathrm{~s}$ rest time was employed between consecutive cycles.

At $70 \% \mathrm{RH}$, a stepwise increase in CAEE was observed in the fractal PEMFCs for each current density cycle, as shown in Fig. 8(a). The CAEE increase in the 1-way fractal PEMFC happens in discrete steps, with no observed activity between cycles. The inter-cycle region is essentially an "OCV - low current" region between two consecutive cycles, with minimal electrochemical activity and its associated water generation, resulting in zero or insignificant acoustic activity. The presence of such discrete CAEE steps during operation of the 1-way fractal PEMFC suggests the following: (i) water generation in the 1-way fractal flow-field is consistent with the electrochemical activity occurring inside the cell and (ii) the 1-way fractal flow-field is very efficient at flushing water out of the cell, as noted in Section 3.2. However, the CAEE increase in the 2-way fractal PEMFC occurred continuously, even between cycles, which can be attributed to the constant generation of acoustic activity resulting from liquid water stagnation and flooding in the flow-field, even when no electrochemical reaction is occur- a)

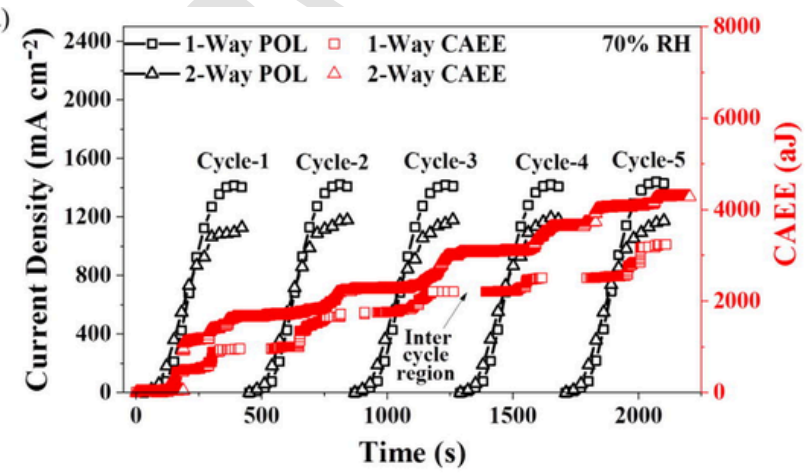

b)

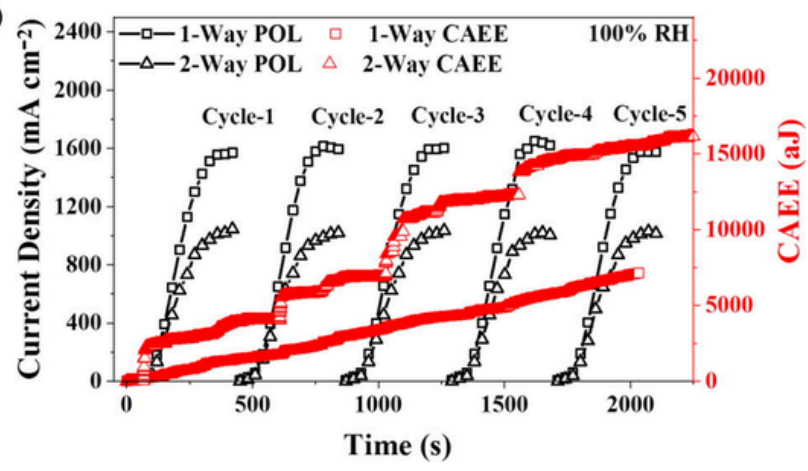

Fig. 8. Successive cycling (five consecutive polarisations) of 1-way and 2-way fractal PEMFCs between OCV and limiting current density with simultaneous acoustic emission (CAEE) measurements at (a) 70\% reactant $\mathrm{RH}$ and (b) 100\% reactant $\mathrm{RH}$.

ring. Overall, at the end of five consecutive current cycles, the 2-way fractal PEMFC delivered lower performance with a relatively higher CAEE generated $(\sim 4400$ aJ), as a result of flooding, compared to the 1-way fractal PEMFC, which delivered consistently better performance with lower CAEE generated $(\sim 3300 \mathrm{aJ})$.

With an increase in reactant humidity to $100 \% \mathrm{RH}$, the CAEE for both fractal PEMFCs, as shown in Fig. 8(b), grew continuously in relatively smaller and larger steps for the 1-way and 2-way fractal PEMFCs, respectively. This continuous increase in CAEE, including between cycles, can be attributed to the constant accumulation of water in the flow-fields due to condensation of water in the high-humidity cathode environment (100\% RH), in addition to the water generated from electrochemical reaction. Condensation in a high-humidity environment at the cathode can be confirmed from the presence of CAEE in the inter-cycle region (Fig. 8(b)) for the 1-way fractal PEMFC, which was absent at $70 \%$ RH (Fig. 8(a)). 
The total CAEE generated after 5 cycles for the 1-way fractal and 2-way fractal PEMFCs at $100 \%$ RH was $\sim 7000$ aJ and $\sim 16500$ aJ, respectively. Thus, the total CAEE increased by 2.3 times and 4 times for 1-way and 2-way fractal PEMFCs, respectively, when the reactant RH increased from $70 \% \mathrm{RH}$ to $100 \% \mathrm{RH}$. This further supports excessive flooding at $100 \% \mathrm{RH}$, consistent with a lower cell performance (Fig. 4) and temperature (Fig. 7).

A detailed analysis of the peak amplitudes of the acoustic hits generated during current density cycling studies and quantification of the water generation in the cells is presented in the Supplementary Material.

\subsection{Cell voltage fluctuation}

Galvanostatic testing was performed on the fractal PEMFCs by operating them at a constant current density of $1000 \mathrm{~mA} \mathrm{~cm}^{-2}$ and $70 \%$ reactant $\mathrm{RH}$ for a little over three hours $(\sim 2000 \mathrm{~s})$. The corresponding cell voltage fluctuation and CAEE measured over time are presented in Fig. 9. Up until $2500 \mathrm{~s}$, there is a continuous increase in CAEE for both fractal PEMFCs and the corresponding cell voltage remains almost constant in this region. This can be identified as the stabilisation phase in fractal PEMFC operation, where reactants, humidification and liquid water within the cell are developing into a steady state condition $[28,32]$.

In the $\sim 2500 \mathrm{~s}$ to $\sim 4000 \mathrm{~s}$ region, the CAEE increase for the 2-way fractal PEMFC is greater than that observed for the 1-way fractal PEMFC. Increased acoustic activity in the 2-way fractal PEMFC can be attributed to increased flooding events occurring inside the cell, which leads to intermittent fluctuations in the cell voltage, as shown in Fig. 9 [7]. The number and magnitude of fluctuations and spikes in the cell voltage is a measure of the non-uniformity of water distribution inside the cell $[56,57]$. Furthermore, the CAEE for the 2-way fractal PEMFC continues to steadily increase between $\sim 4000 \mathrm{~s}$ and $\sim 9000 \mathrm{~s}$, with a corresponding increase in both the number and magnitude of the cell voltage fluctuations and spikes. After $\sim 9000 \mathrm{~s}$, the cell voltage starts to drop continuously, instead of fluctuating, in the 2-way fractal PEMFC, and the corresponding CAEE increases in larger steps. Such large-step increase in CAEE occurs due to the more significant water retention in the 2-way fractal PEMFC, which continuously floods the cell and reduces its voltage [16].

In contrast, the cell voltage for the 1-way fractal PEMFC remains almost constant, with minor increases in CAEE beyond $3000 \mathrm{~s}$, compared to the fluctuating cell voltage observed for the 2-way fractal PEMFC. This is due to more effective water removal from the cell, resulting in less water retention at the flow-fields and associated generated acoustic activity [32].

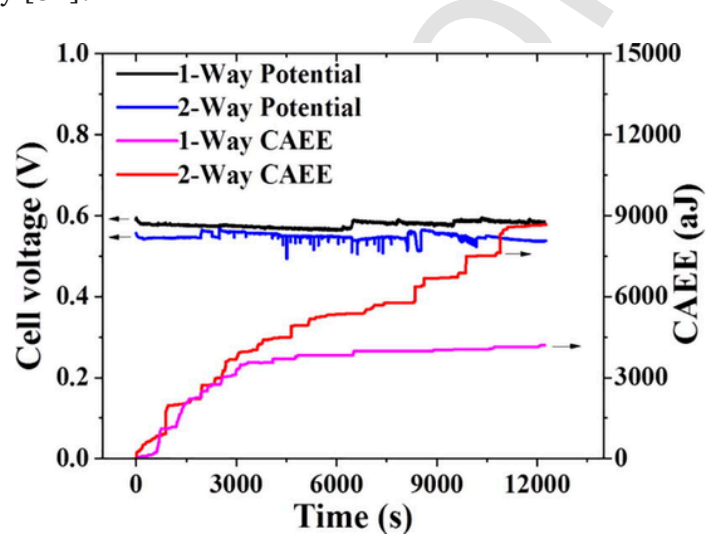

Fig. 9. Cell voltage fluctuations at current hold $\left(1000 \mathrm{~mA} \mathrm{~cm}^{-2}\right)$ for fractal PEMFCs with simultaneous CAEE measurements at 70\% reactant $\mathrm{RH}$.

\section{Conclusions}

This study presented the design and development of a new 2-way fractal flow-field that has an increased contact area, but a more convoluted water removal path compared to the previously reported 1-way fractal flow-field, which has less contact area but a direct water egress path from the cell surface. The influence of contact area and water removal mechanism on the performance delivered by the fractal PEMFCs was investigated. Furthermore, this study is the first to utilise an acoustic emission technique as a hydration diagnostic tool to understand and diagnose water management inside both these fractal PEMFCs.

Features that are indicative of the quality of fabrication of the flow-fields were demonstrated via X-ray CT scan imaging, which showed proper alignment between individual plates in the overall assembly. The 2-way fractal PEMFC delivered better performance in the Ohmic region of operation: $0-700 \mathrm{~mA} \mathrm{~cm}{ }^{-2}$ at $70 \% \mathrm{RH}$ and $0-400 \mathrm{~mA} \mathrm{~cm}^{-2}$ at $100 \%$ $\mathrm{RH}$. Beyond this, its performance degraded drastically compared to the 1-way fractal PEMFC, as a result of severe cell flooding. Good correlation was observed between complementary measurements of cell polarisation curves, acoustic activity, temperature and cell voltage fluctuation during galvanostatic testing.

Further efforts are ongoing to address the design of the reactant flow outlet path in the 2-way fractal system by making it less convoluted, which should result in better overall performance, particularly in the mass transport limited region.

\section{CRediT authorship contribution statement}

V.S. Bethapudi: Conceptualization, Methodology, Formal analysis, Validation, Investigation, Visualization, Writing - original draft. J. Hack: Methodology, Visualization. P. Trogadas: Validation. G. Hinds: Writing - review \& editing, Funding acquisition, Supervision. P.R. Shearing: Resources, Funding acquisition. D.J.L. Brett: Conceptualization, Investigation, Resources, Writing - review \& editing, Funding acquisition, Supervision, Project administration. M.-O. Coppens: Conceptualization, Investigation, Resources, Writing - review \& editing, Funding acquisition, Supervision, Project administration.

\section{Declaration of Competing Interest}

The authors declare that they have no known competing financial interests or personal relationships that could have appeared to influence the work reported in this paper.

\section{Acknowledgements}

The authors would like to acknowledge funding from the EPSRC for the Centre for Nature-Inspired Engineering (EP/K038656/1 and EP/ S03305X/1), and for supporting fuel cell research in the Electrochemical Innovation Lab (EP/L015277/1, EP/P009050/1, EP/M014371/1, EP/ M009394/1, EP/M023508/1, EP/L015749/1, and EP/N022971/1). We also thank the Department of Chemical Engineering, University College London, and the National Measurement System of the UK Department of Business, Energy and Industrial Strategy for supporting this work. Jennifer Hack acknowledges a studentship from the EPSRC Centre for Doctoral Training in Advanced Characterisation of Materials (EP/LO15277/ 1).

The authors would like to acknowledge Dr. Quentin Meyer and Professor Daniel Steingart for their assistance in sourcing the equipment and supplying the interfacing code used to obtain the data. 


\section{Appendix A. Supplementary data}

Supplementary data to this article can be found online at https://doi. org/10.1016/j.enconman.2020.113083.

\section{References}

[1] M Andersson, S B Beale, M Espinoza, Z Wu, W Lehnert A review of cell-scale multiphase flow modeling, including water management, in polymer electrolyte fuel cells. Appl Energy 2016;180:757-778. doi:10.1016/j.apenergy.2016.08.010.

[2] M M Nasef, A A Aly Water and charge transport models in proton exchange membranes: an overview. Desalination 2012;287:238-246. doi:10.1016/ j.desal.2011.06.054.

[3] B H Lim, E H Majlan, W R W Daud, T Husaini, M I Rosli Effects of flow field design on water management and reactant distribution in PEMFC: a review. Ionics (Kiel) 2016;22:301-316. doi:10.1007/s11581-016-1644-y.

[4] H Li, Y Tang, Z Wang, Z Shi, S Wu, D Song, et al. A review of water flooding issues in the proton exchange membrane fuel cell. J Power Sources 2008;178:103-117. doi:10.1016/j.jpowsour.2007.12.068.

[5] N J Steffy, S V Selvaganesh, M Kumar, A K Sahu Online monitoring of fuel starvation and water management in an operating polymer electrolyte membrane fuel cell by a novel diagnostic tool based on total harmonic distortion analysis. $\mathrm{J}$ Power Sources 2018;404:81-88. doi:10.1016/j.jpowsour.2018.10.012.

[6] D Hissel, M C Pera Diagnostic \& health management of fuel cell systems: issues and solutions. Annu Rev Control 2016;42:201-211. doi:10.1016/ j.arcontrol.2016.09.005

[7] T J Mason, J Millichamp, T P Neville, P R Shearing, S Simons, D J L Brett A study of the effect of water management and electrode flooding on the dimensional change of polymer electrolyte fuel cells. J Power Sources 2013;242:70-77. doi:10.1016/j.jpowsour.2013.05.045.

[8] Y Yu, B Chen, C Zhang, Z Tu, T Yang, S H Chan, et al. Carbon corrosion and performance degradation mechanism in a proton exchange membrane fuel cell with dead-ended anode and cathode. Energy 2016;106:54-62. doi:10.1016/ j.energy.2016.03.045

[9] S Chevalier, N Ge, R Yip, P Antonacci, A Bazylak, J Lee Feasibility of combining electrochemical impedance spectroscopy and synchrotron X-ray radiography for determining the influence of liquid water on polymer electrolyte membrane fuel cell performance. Int J Hydrogen Energy 2015;40:16494-16502. doi:10.1016/ j.ijhydene.2015.10.008

[10] P Rahimian, L Zhang, L Battrell, R Anderson, N Zhu, E Johnson Investigation of time dependent water droplet dynamics on porous fuel cell material via synchrotron based X-ray imaging technique. Exp Therm Fluid Sci 2018;97:237-245. doi:10.1016/j.expthermflusci.2018.04.021.

[11] S S Alrwashdeh, H Markotter, J Haussmann, A Hilger, I Manke, J Scholta X-ray tomographic investigation of water distribution in polymer electrolyte membrane fuel cells with different gas diffusion media. ECS Trans 2016;72:99-106. doi:10.1149/07208.0099ecst.

[12] I V Zenyuk, D Y Parkinson, G Hwang, A Z Weber Probing water distribution in compressed fuel-cell gas-diffusion layers using $\mathrm{X}$-ray computed tomography. Electrochem Commun 2015;53:24-28. doi:10.1016/j.elecom.2015.02.005.

[13] J A Salva, A Iranzo, F Rosa, E Tapia Validation of cell voltage and water content in a PEM (polymer electrolyte membrane) fuel cell model using neutron imaging for different operating conditions. Energy 2016;101:100-112. doi:10.1016/ j.energy.2016.02.006.

[14] J I S Cho, T P Neville, P Trogadas, Q Meyer, Y Wu, R Ziesche, et al. Visualization of liquid water in a lung-inspired flow-field based polymer electrolyte membrane fuel cell via neutron radiography. Energy 2018;170:14-21. doi:10.1016/ J.ENERGY.2018.12.143.

[15] Y Wu, J I S Cho, T P Neville, Q Meyer, R Ziesche, P Boillat, et al. E ff ect of serpentine $\mathrm{fl}$ ow- fi eld design on the water management of polymer electrolyte fuel cells: an in-operando neutron radiography study. J Power Sources 2018;399:254-263. doi:10.1016/j.jpowsour.2018.07.085.

[16] K Tüber, D Pócza, C Hebling Visualization of water buildup in the cathode of a transparent PEM fuel cell. J Power Sources 2003;124:403-414. doi:10.1016/ S0378-7753(03)00797-3.

[17] H Guo, X Liu, J F Zhao, F Ye, C F Ma Experimental study of two-phase flow in a proton exchange membrane fuel cell in short-term microgravity condition. Appl Energy 2014;136:509-518. doi:10.1016/j.apenergy.2014.09.058.

[18] F T Man Real-time testing of automatic overload control systems in a laboratory environment. IEEE Trans Commun 1973;21:1027-1031. doi:10.1109/ TCOM.1973.1091787.

[19] J Kiselev, B Ziegler, H J Schwalbe, R P Franke, U Wolf Detection of osteoarthritis using acoustic emission analysis R. Med Eng Phys 2019;65:57-60. doi:10.1016/ j.medengphy.2019.01.002.

[20] D G Aggelis, E Z Kordatos, T E Matikas Acoustic emission for fatigue damage characterization in metal plates. Mech Res Commun 2011;38:106-110. doi:10.1016/j.mechrescom.2011.01.011.

[21] Z Zhang, X Wu, J Tan In-situ monitoring of stress corrosion cracking of 304 stainless steel in high-temperature water by analyzing acoustic emission waveform. Corros Sci 2019;146:90-98. doi:10.1016/j.corsci.2018.10.022.

[22] A Zaki, H K Chai, A Behnia, D G Aggelis, J Y Tan, Z Ibrahim Monitoring fracture of steel corroded reinforced concrete members under flexure by acoustic emission technique. Constr Build Mater 2017;136:609-618. doi:10.1016/ j.conbuildmat.2016.11.079.
[23] Q Lemarié, F Alloin, P X Thivel, H Idrissi, L Roué Study of sulfur-based electrodes by operando acoustic emission. Electrochim Acta 2019;299:415-422. doi:10.1016/j.electacta.2019.01.019.

[24] J B Robinson, M Maier, G Alster, T Compton, D J L Brett, P R Shearing Spatially resolved ultrasound diagnostics of Li-ion battery electrodes. Phys Chem Chem Phys 2019;21:6354-6361. doi:10.1039/c8cp07098a.

[25] N Beganovic, D Söffker Estimation of remaining useful lifetime of lithium-ion battery based on acoustic emission measurements. J Energy Resour Technol Trans ASME 2019;141:1-10. doi:10.1115/1.4042234.

[26] L Oca, N Guillet, R Tessard, U Iraola Lithium-ion capacitor safety assessment under electrical abuse tests based on ultrasound characterization and cell opening. J Energy Storage 2019;23:29-36. doi:10.1016/j.est.2019.02.033.

[27] M Maier, Q Meyer, J Majasan, C Tan, I Dedigama, J Robinson, et al. Operando flow regime diagnosis using acoustic emission in a polymer electrolyte membrane water electrolyser. J Power Sources 2019;424:138-149. doi:10.1016/ j.jpowsour.2019.03.061.

[28] B Legros, P X Thivel, Y Bultel, M Boinet, R P Nogueira Acoustic emission: towards a real-time diagnosis technique for Proton exchange membrane fuel cell operation. J Power Sources 2010;195:8124-8133. doi:10.1016/ j.jpowsour.2010.07.045.

[29] J Malzbender, R W Steinbrech Advanced measurement techniques to characterize thermo-mechanical aspects of solid oxide fuel cells. J Power Sources 2007;173:60-67. doi:10.1016/j.jpowsour.2007.07.072.

[30] B Legros, R P Nogueira, P-X Thivel, Y Bultel, M Boinet Electrochemical impedance and acoustic emission survey of water desorption in nafion membranes. Electrochem Solid-State Lett 2009;12:B116. doi:10.1149/1.3131728.

[31] B Legros, P X Thivel, F Druart, Y Bultel, R Nogueira Diagnosis and modelling of proton- exchange-membrane fuel cell via and acoustic-emission measurements. Electromotion 2009;1-6. doi:10.1109/ELECTROMOTION.2009.5259133.

[32] V S Bethapudi, M Maier, G Hinds, P R Shearing, D J L Brett, M O Coppens Acoustic emission as a function of polarisation: diagnosis of polymer electrolyte fuel cell hydration state. Electrochem Commun 2019;109:106582. doi:10.1016/ j.elecom.2019.106582.

[33] P Trogadas, J I S Cho, T P Neville, J Marquis, B Wu, D J L Brett, et al. A lung-inspired approach to scalable and robust fuel cell design. Energy Environ Sci 2018;11:136-143. doi:10.1039/c7ee02161e.

[34] J. Marquis, PhD thesis, Rensselaer Polytechnic Institute, Troy, NY; 2013.

[35] J I S Cho, J Marquis, P Trogadas, T P Neville, D J L Brett, M O Coppen Optimizing the architecture of lung-inspired fuel cells. Chem Eng Sci 2019;115375. doi:10.1016/j.ces.2019.115375.

[36] P Trogadas, M-O Coppens Nature-inspired electrocatalysts and devices for energy conversion. Chem Soc Rev 2020. doi:10.1039/c8cs00797g.

[37] S Kjelstrup, M O Coppens, J G Pharoah, P Pfeifer Nature-inspired energy-and material-efficient design of a polymer electrolyte membrane fuel cell. Energy Fuels 2010;24:5097-5108. doi:10.1021/ef100610w.

[38] M O Coppens A nature-inspired approach to reactor and catalysis engineering. Curr Opin Chem Eng 2012;1:281-289. doi:10.1016/j.coche.2012.03.002.

[39] V S Bethapudi, J Hack, P Trogadas, J I S Cho, L Rasha, G Hinds, et al. A lung-inspired printed circuit board polymer electrolyte fuel cell. Energy Convers Manage 2019;202:112198. doi:10.1016/j.enconman.2019.112198.

[40] Q Meyer, N Mansor, F Iacoviello, P L Cullen, R Jervis, D Finegan, et al. Investigation of hot pressed polymer electrolyte fuel cell assemblies via X-ray computed tomography. Electrochim Acta 2017;242:125-136. doi:10.1016/ j.electacta.2017.05.028.

[41] J Shen, L Xu, H Chang, Z Tu, S H Chan Partial flooding and its effect on the performance of a proton exchange membrane fuel cell. Energy Convers Manage 2020;207:112537. doi:10.1016/j.enconman.2020.112537.

[42] O S Ijaodola, Z El- Hassan, E Ogungbemi, F N Khatib, T Wilberforce, J Thompson, et al. Energy efficiency improvements by investigating the water flooding management on proton exchange membrane fuel cell (PEMFC). Energy 2019;179:246-267. doi:10.1016/j.energy.2019.04.074.

[43] H Heidary, M Jafar Kermani, N Khajeh-Hosseini-Dalasm Performance analysis of PEM fuel cells cathode catalyst layer at various operating conditions. Int $\mathrm{J}$ Hydrogen Energy 2016;41:22274-22284. doi:10.1016/j.ijhydene.2016.08.178.

[44] P Deevanhxay, T Sasabe, S Tsushima, S Hirai Effect of liquid water distribution in gas diffusion media with and without microporous layer on PEM fuel cell performance. Electrochem Commun 2013;34:239-241. doi:10.1016/ j.elecom.2013.07.001.

[45] M A Rubio, A Urquia, S Dormido Diagnosis of performance degradation phenomena in PEM fuel cells. Int J Hydrogen Energy 2010;35:2586-2590. doi:10.1016/j.ijhydene.2009.03.054.

[46] H Xu, H R Kunz, J M Fenton Analysis of proton exchange membrane fuel cell polarization losses at elevated temperature $120{ }^{\circ} \mathrm{C}$ and reduced relative humidity. Electrochim Acta 2007;52:3525-3533. doi:10.1016/j.electacta.2006.10.015.

[47] D H Jeon, K N Kim, S M Baek, J H Nam The effect of relative humidity of the cathode on the performance and the uniformity of PEM fuel cells. Int J Hydrogen Energy 2011;36:12499-12511. doi:10.1016/j.ijhydene.2011.06.136.

[48] K R Cooper, M Smith Electrical test methods for on-line fuel cell ohmic resistance measurement. J Power Sources 2006;160:1088-1095. doi:10.1016/ j.jpowsour.2006.02.086.

[49] S Asghari, A Mokmeli, M Samavati Study of PEM fuel cell performance by electrochemical impedance spectroscopy. Int J Hydrogen Energy 2010;35:9283-9290. doi:10.1016/j.ijhydene.2010.03.069.

[50] N Ge, R Banerjee, D Muirhead, J Lee, H Liu, P Shrestha, et al. Membrane dehydration with increasing current density at high inlet gas relative humidity in polymer electrolyte membrane fuel cells. J Power Sources 2019;422:163-174. doi:10.1016/j.jpowsour.2019.03.001.

[51] D Candusso, D Hissel, A Hernandez, A Aslanides A review on PEM voltage degradation associated with water management: impacts, influent factors 
and characterization. J Power Sources 2008;183:260-274. doi:10.1016/ j.jpowsour.2008.04.037.

[52] X Yuan, J C Sun, M Blanco, H Wang, J Zhang, D P Wilkinson AC impedance diagnosis of a 500 W PEM fuel cell stack. Part I: stack impedance. J Power Sources 2006;161:920-928. doi:10.1016/j.jpowsour.2006.05.003.

[53] S Shimpalee, U Beuscher, J W Van Zee Analysis of GDL flooding effects on PEMFC performance. Electrochim Acta 2007;52:6748-6754. doi:10.1016/ j.electacta.2007.04.115.

[54] C Song, Y Tang, J L Zhang, J Zhang, H Wang, J Shen, et al. PEM fuel cell reaction kinetics in the temperature range of $23-120^{\circ} \mathrm{C}$. Electrochim Acta 2007;52:2552-2561. doi:10.1016/j.electacta.2006.09.008.
[55] D N Ozen, B Timurkutluk, K Altinisik Effects of operation temperature and reactant gas humidity levels on performance of PEM fuel cells. Renew Sustain Energy Rev 2016;59:1298-1306. doi:10.1016/j.rser.2016.01.040.

[56] J R Atkins, S C Savett, S E Creager Large-scale current fluctuations in PEM fuel cells operating with reduced feed stream humidification. J Power Sources 2004;128:201-207. doi:10.1016/j.jpowsour.2003.09.067.

[57] Y Yang, X Zhang, L Guo, H Liu Mechanisms of voltage spikes and mitigation strategies for proton exchange membrane fuel cells with dead-ended anode under pressure swing operation. Int J Hydrogen Energy 2017;42:28578-28587. doi:10.1016/j.ijhydene.2017.09.103. 